\title{
Ben Wildvsky: The great brain race: How global universities are reshaping the world. Princeton University Press, Princeton \& Oxford, 2010, xiii, pp. 1-240
}

\author{
Wanhua Ma
}

Published online: 24 March 2011

(C) The Author(s) 2011. This article is published with open access at Springerlink.com

The book consists of six chapters with an introduction and afterword. Based on more than one hundred interviews conducted in India, Western Europe, the Middle East, the United States and China, the author identifies several important issues in higher education globalization. The global race for talents, branching out of universities, the wanted "WorldClass" universities, the worldwide university rankings, the global expansion of for-profit institutions and the free-trade in minds are the major themes for discussion. Through the discussion, the author expresses the idea that higher education like any other industry is already very much globalized.

In Chapter 1, the author reviews the history of student mobility and finds it natural for students and scholars moving around for knowledge since the appearance of universities in the 1220s. But most of the mobile students were in European countries such as the UK, Italy, France and Germany, and even in the first half of the 20th century many US students went to Europe for Ph.D. education. It was only after the Second World War that the moving direction changed with the growing strength of American research universities. For about the last 50 years, the US takes the lead for foreign students' enrollment, though competition for those students is high. According to the author, there are political and economical reasons for the competition. Many countries have their own purposes, and for the United State, establishing exchange programs and attracting more students is for "soft diplomacy." This could be easily observed in Fulbright program's website.

Besides student mobility, the mobility of administrators and faculty should also be considered as part of the globalization process. The most convincing examples are the traditional elite universities like Oxford and Cambridge in the UK that have to hire their vice chancellors from other parts of the world for innovative leadership. In competing for talents, universities in China and India also used different strategies. But with a careful examination, the author finds that the terms "brain circulation" or "brain exchange" in most cases are only applicable to the developed countries, which means the developed countries benefit the most from the whole process. Besides physical mobility of faculty,

\footnotetext{
W. Ma $(\bowtie)$

The Center for International Higher Education, Graduate School of Education, Peking University, 100871 Beijing, China

e-mail: hma@pku.edu.cn
} 
students and administrators, the author also finds the uniqueness of current higher education globalization that is "a state of mind." Many top private university administrators, such as Yale and Stanford, in the US think and act globally.

The surplus of higher education resources, the shrinking of financial support in the developed countries and the growing demand for Western-style education are the primary reasons for many Western universities to behave like for-profit companies. This entrepreneur behavior can be easily observed in university "branching out" activities. In Chapter 2, the author noticed that recently branch campuses mushroom in the Middle and Far East. Especially for American research universities, most of the branch campuses are in oil-rich countries of the Middle East. Through some case analysis, the author finds that the proliferation of the branch campuses does not mean they are free of obstacles or complications. In fact, the complications could involve many things, including political, financial and cultural concerns. Through the discussion of different views and concerns on the branch campuses, the author points out the improvement of the quality of education in order to protect the brand name seem to be the major challenge. Despite various challenges or concerns, the author predicts the global presence of the most successful universities is likely to continue.

American higher education has been used as a model for development by many countries. Since American research universities are so competitive globally, other countries desire to have similar universities. Building "world-class university" became an important policy in China since 1998. In Chapter 3, the author analyzes China's effort on the building of "world-class" and its effect on global higher education. At the beginning of the 21 st Century, the "world-class" concept quickly spread out to other countries in East Asia and then to countries in Europe. National governments change their higher education policies by allocating more funds to top universities and by reorganizing their higher education systems. Even in the Middle East, millions of dollars are used for the ambition of creating a brand new research university like MIT or Stanford. According to the author, whether those policies and strategies could guarantee the success of those activities depends very much on the universities' knowledge production and expansion.

What is the world-class university? Many researchers find it hard to define. It is very natural that in the process of "world-class" building, there is a need for something that could measure the development, so comes the global university ranking. In Chapter 4, the author reviews the historical development of college ranking in the US. College ranking has a long history in the US with different purposes, and it is often criticized by the university presidents, because they considered universities could not be measured by numbers. And nobody then could imagine that college rankings can go global. When Shanghai Jiaotong University published its ranking result in 2004, the whole world of higher education was shocked. How a university could be measured was the first reaction of researchers and administers. But the industry did not stop there; many other rankings followed the example. According to the author, now totally, there are more than 40 national ranking institutions in the world. There must be a market for the proliferation of the ranking industry. Many rankings are used by governments for policy purposes and by institutions for development reasons. But the author finds that none of the rankings seems to provide good guidance to students about university quality.

The process of going global also includes the for-profit education organizations. In Chapter 5, the author notes a few well-known for-profit organizations in the US have already made their global presence. The author discusses many examples of such for-profit organization, and the Apollo Global is one of the them. According to the author, in the global market of higher education, a whole for-profit education industry has already been 
established. If the test preparation business is considered part of the industry, the testing companies, certification organizations and overseas study consulting companies would all be other parts of the industry. Education for-profit organziations take many forms, and currently, the author points out, the "plugged-in learning" is the easiest way to reach millions of people through technology.

The author also offers a distinction between the reach out of the nonprofit institutions and the for-profit institutions. The use of "academic rigor", "reputation and brand awareness" and a US degree are the non-profit university strategies, while the for-profit universities or education companies are very much local-need oriented. In recent years, the for-profit institutions grow very fast in many parts of the world. But, again, how to control the quality is a major concern. And it is not easy to restrict those commercial behaviors of multi-national for-profit education institutions. Especially after GATS, the author notes that even regulation on students, faculty and ideas circulation become difficult, when higher education is part of the "international trade."

In Chapter 6, the author creates a new term to describe the marketization of higher education, "free trade in minds," meaning "a global brand mentality in choosing the universities at which they pursue best available scholarly destinations, with little regard to national boundaries." The author recognizes that higher education as trade is different from other kinds of trade, because of "the fluidity, mobility and meritocracy" in nature. The "free trade in minds" may cause different kinds of academic protections. When governments see the competitive threats in higher education globalization, strategies or policies could be adopted to protect national interests; changing immigration policy and limiting scholarships for international students in certain fields of study are the possibilities. But in a free market competition, the author insists on the removal of the academic protectionism.

Based on his analysis in the six chapters, the author concludes that the current globalization movement for higher education is far-reaching in transforming the global academic order. In the past 50 years, the American research universities have served as unsurpassed magnets for students and faculty around the world. The current economic globalization and the opening up of developing nations in Asia and other areas create more challenges and opportunities for American research universities Those challenges the author considers as "a sense of possibility" rather than "a cause for panic," for the world's prosperity needs American research universities' idea and knowledge.

With a neo liberal perspective, the author believes that global competition in higher education does not mean one winner with all others as losers. It is possible to create a winwin situation for those nations that quickly lower their academic barriers. But the question is whether higher education could be really treated as other kinds of goods. In the book, the concept of "free trade in minds" is really challenging, because higher education carries many other meanings to a nation, an institution and an individual. It is different from other trade in goods.

One thing the author fails to do is the introduction of his interviewees. He should at least provide some basic information on who they are. The introduction will help readers to have a better orientation on many of the arguments. In general, the book is well-written, and the author offers a good interpretation of his interview data. The book summarizes what has happened to higher education in globalization, and the reviewer strongly recommends it to policy-makers, university administrators, researchers and graduate students in the field.

Open Access This article is distributed under the terms of the Creative Commons Attribution Noncommercial License which permits any noncommercial use, distribution, and reproduction in any medium, provided the original author(s) and source are credited. 